\title{
Wild grapes of Kuban, their ecological and biological features of growth
}

\author{
Ivan Gorbunov ${ }^{1 *}$, Stanislav Mikhailovskiy ${ }^{1}$, Olga Byhalova $^{2}$ \\ ${ }^{1}$ Anapa Zonal Experimental Station of Viticulture and Wine-making - branch of Federal State Budget \\ Scientific Institution "North Caucasian Federal Scientific Center of Horticulture, Viticulture, Wine- \\ making", 36 ave. Pionersky, Anapa, 353456, Russia \\ ${ }^{2}$ Federal State Budgetary Institution "State Nature Reserve "Utrish", 41 str. Severnaya, Anapa, \\ 353445, Russia
}

\begin{abstract}
The biodiversity of the Vitaceae Juss family is studied with more interest than before, but still not fully according to the current scientific literature. For example, indigenous varieties and wild forms of grapes are known in the Crimea, Dagestan, along the banks of the Don and in other regions, but there is practically no data about wild and autochthonic grapes in the Kuban. This work presents new data about wild grapes studied in the Krasnodar region in the forests of the "Red forest" reserve. The ecological and geographical conditions of their growth are studied in detail. The description of plant community where the studied plant forms grow is conducted. Isolated populations of wild grapes, presumably belonging to the species of Vitis vinifera ssp. silvestris Gmel. or its varieties - var. Tipica Negr. (typical wild forest grapes) were ampelographically studied. Samples were taken for further genetic analysis to identify the origin of these forms and identify promising donors of resistance to various environmental stressors for use in the breeding process.
\end{abstract}

\section{Introduction}

The wild grape form (Vitis vinifera ssp. silvestris Gmel. and its existing varieties) are forest climbing plants that grow in separate populations [1]. According to world research, the wildgrowing subspecies of the cultivated grape - Vitis vinifera ssp. silvestris Gmel. is considered as the ancestor of extant varieties [2-11].

Grapes are the only species of cultivated plants that have an indigenous origin in Eurasia. It appeared more than 65 million years ago [12]. Historically, it was divided into subspecies much later, due to differences in the morphology of this plant [13]. The grape is a unique plant, as it is the main agricultural crop, and it also has ancient historical roots with the development of human culture and civilization [14-15].

The literature provides information about indigenous grape varieties in the territories of Crimea, Dagestan, along the banks of the Don [16], but there are none in the Kuban.

\footnotetext{
*Corresponding author: wunsch27@mail.ru
} 


\section{Materials and methods}

In May-June 2020, expedition work was conducted on the territory of the State Nature Reserve "Red forest" in order to search for wild forms of grapes, study their ecological growing conditions and morpho-biological features.

The study of wild grapes was carried out by the route-reconnaissance method with application of the traditional method of geobotanical research. At the same time the topography of habitats, the structure and floral composition of plant communities where wild forms of grapes grow were studied [17]; the brief description of vegetation was given. Morphological features of vegetative and generative organs of wild grape forms are studied using the ampelographic description method. The most variable morphological features of the studied plants are shown. Samples were taken (the top of a young shoot) for molecular and genetic analysis of wild grape forms.

\section{Results and discussion}

The territory of the reserve covers an area of 5100 ha This is one of the largest woodlands of the steppe plain area of the Krasnodar region, representing the remains of wooded areas that once framed the right bank of the Kuban river in a wide strip, up to its delta. Nowadays, it looks like an island that is washed by the Kuban river for six kilometers. The top storey is represented by the pollard oak (Quercus robur L.), which is the main forest-forming species of this massif and includes fresh and wet groups of forest types. Oak companions are: European ash (Fraxinus excelsior L.), European hornbeam (Carpinus betulus L.), English field maple (Acer campestre L.), Tartarian maple (Acer tataricum L.), Caucasian pear (Pyrus caucasica Fed.), Oriental wild Apple (Malus orientalis Uglitzk.), elm. The age of oak stands ranges from 60 to 100 years Average diameter $-24-28 \mathrm{~cm}$, maximum $-44 \mathrm{~cm}$. Average height $-24.0-28.5 \mathrm{~m}$. Density of stocking - 0.7. Bonitet -2 .

A significant part of the oak stands have been replaced for various reasons by stands of European ash nowadays. Ash formations are 60-80 years old. The average height of those species varies from 23.0 to $29.0 \mathrm{~m}$ with a diameter of $18-28 \mathrm{~cm}$ and a bonitet -1 . Occasionally, there are also older ash trees (100 or more years old). Only a few trees of white poplar (Populus alba L.) and European willow (Salix alba L.) are located in the wet group of forest types on this territory.

The undergrowth is well defined and represented by: European cornel (Cornus mas L.), southern svidina (Swida australis (C.A.Mey.) Pojark. ex Grossh.), single-seed hawthorn (Crataegus monogyna Jacq.), small-flowered black hawthorn (Crataegus pentagyna W. et L.), common hazel (Corylus avellana L.), European barberry (Berberis vulgaris L.), black elder (Sambucus nigra L.), guelder-rose (Viburnum opulus L.), brere (Rosa canina L.), European dewberry (Rubus caesius L.), alycha (Prunus divaricata Ehrh.), black thorn (Prunus spinosa L.), louseberry (Euonymus europaeus L.), etc. In inundable massifs lianas represened by woodland grape, which locally form dense, impenetrable brushwood, less often along the edges. In the meander part can be found common hop (Humulus lupulus L.).

Grass canopy in closed woodlands does not form ramping. The total projection coverage is $30 \%$, in case of incompact crown cover it can reach $70 \%$. Structure of vegetation layer: wood violet (Viola sylvatica Fr.), purple gromwell (Lysimachia atropurpurea L.), wood spurge (Euphorbia amygdaloides L.), common avens (Geum urhanum L.), herb Robert (Geranium robertianum L.), hariff (Galium aparine L.), damewort (Hesperis matronalis L.). In some places there is development of nettle (Urtica L.) in the shape of synusia; its underprush has common avens, hedge nettle (Stachys sylvatica L.), great bindweed (Calystegia silvatica (Kit.) Griseb.), bearbine (Convolvulus L.), etc. In shady places usually grow broad-leaved enchanter's-nightshade (Circaea lutetiana L.), celandrine (Chelidonium 
majus L.); on the edges of forest, near paths and roads grow wood cerastium (Cerastium silvaticum Waldst. \& Kit.), brook-mint (Mentha longifolia (L.) Huds.), varia crown vetch (Coronilla varia (L.) Lassen), Saint-John's-wort (Hypericum perforatum L.), cicksfoot (Dactylis glomerata L.). The undergrowth is represented by specimens: European ash - 5,0 thousand pieces/ha, pollard oak - 1,8 thousand pieces/ha, English field maple - 2,0 thousand pieces/ha, which is confined mainly to the incompact crown cover zone, as well as to the edge of the stands.

Within the forest area of the reserve "Red forest" there are artificial plantings of pollard oak and European ash. Their age is 40-50 years. Height $-18-20$ meters. There is no undergrowth within forest culture. There is partial ramping in mixed oak-ash and ash plantantions.

As a result of the expedition research, 5 populations of wild grapes were discovered and studied, which are completely different in terms of ampelographic description of the vegetative parts of the plant. Ampelographic description was conducted on more than 40 signs of vegetative and generative spheres of wild grape forms, more than 10 of them are the most variable. In particular, it was found that the shape (openness) and weblike hairiness of the growing tip, the setaceous and weblike hairiness of the leaf lower side, the shape of the formed leaf, the depth of the upper side indentations of the leaf, etc.; the studied populations of wild grapes have some of the most variable morphological features. The shape of the top of the young shoot varies in this case from slightly open to fully open. Weblike hairiness of these plants varies from rare ( 2 points) to dense ( 4 points). Setaceous hairiness - from very rare to medium. The leaf shape can be deltoid, rounded, or pentagonal (Fig. 1).

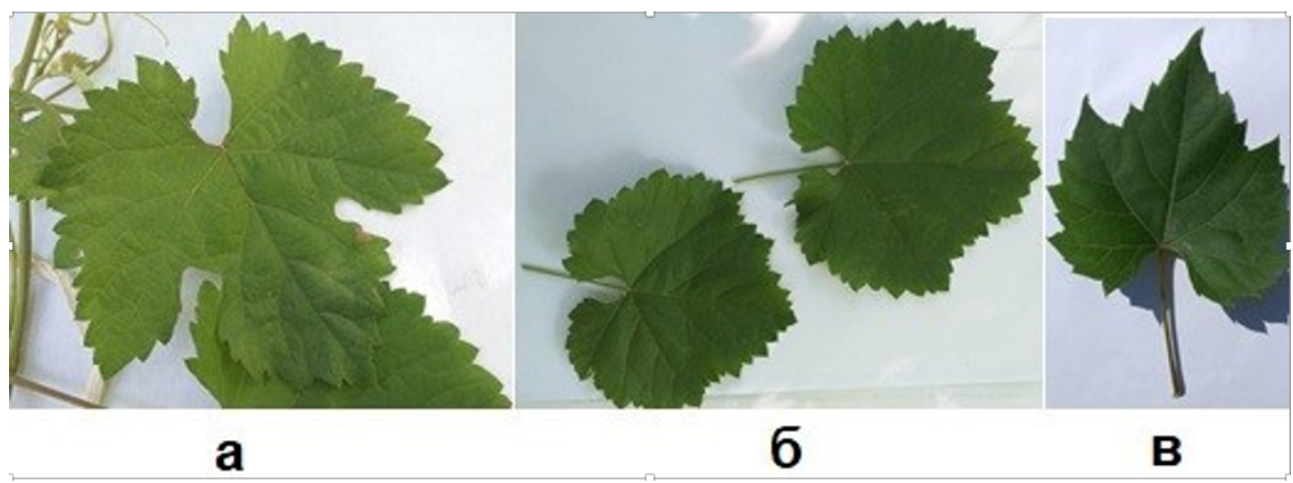

Fig. 1. Various forms of the formed leaf in wild grape forms: a - pentagonal, b - rounded, C - deltoid (Reserve "Red forest", 2020).

The depth of the upper side indentations is from medium to very deep. Moreover, there is a variability of some features at the endogenous level. So, for example, the formed leaves of one plant can have an almost entire leaf blade and parted, and the shape can be deltoid and pentagonal.

The yield per plant was estimated visually. There is a significant number of vines with berries, which indicates a good productivity of these wild forms (Fig. 2). 


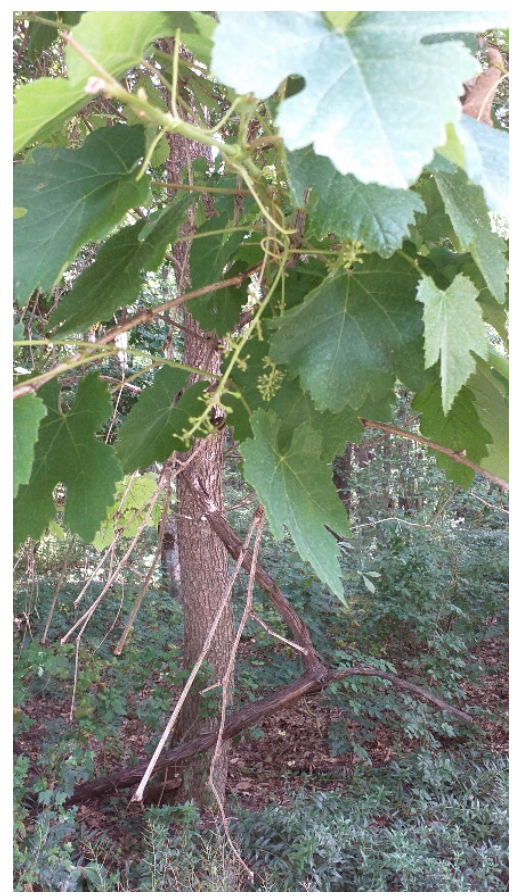

Fig. 2. Yielding vine of wild grapes (Reserve "Red forest", 2020)

According to employees of the reserve "Red forest" these forms of grapes have small almost color berries witn sweet astringent flavor. They are maturing by mid-September.

The affection on plants by pests and diseases was visually estimated. At first sight the studied wild forms of grapes are healthy due to absence of damage traces on plants. Further, it is planned to study the found samples using genetic methods to identify new donors of resistance to various biotic and abiotic environmental factors.

\section{Conclusion}

As the result, for the first time samples of isolated populations of wild grapes were studied and described on the territory of the state nature reserve "Red forest" in the number of 5 populations, the vine of which is not exposed to any of the visually detectable pathogens and pests. Due to the ability of the wild vine to easily interbreed with the cultivated vine, these valuable qualities of wild grapes will be transferred to the cultivated varieties by including them as donors of resistance to biotic and abiotic stressors in the breeding process. Morphobiological study of grape plants and a detailed description of their ecological conditions of growth are conducted. Morphological evaluation of vegetative parts among populations of the studied forms of wild grape showed that the shape (openness), the weblike hairiness of the growing tip, the setaceous and weblike hairiness of the leaf lower side, the shape of the formed leaf, the depth of the upper side indentations of the leaf, etc., are some of the most varied morphological features. For example, the openness of the young shoot coronule varies from slightly open to fully open, and the weblike hairiness changes from medium to very dense, etc. The yield from the plant was not evaluated, but visually we can say about the good productivity of these wild forms. 


\section{References}

1. C. Arnold, A. Schnitzler, C. Parisot, A. Maurin, River Res. Applic., 26, 904-914 (2010) http://doi.org/10.1002/rra.1312

2. V. Laucou, T. Lacombe, F. Dechesne, R. Siret, J.-P. Bruno, M. Dessup, T. Dessup, P. Ortigosa, P. Parra, C. Roux, S. Santoni, D. Varès, J.-P. Péros, J.-M. Boursiquot, P. This, Theor. and Appl. Gen., 122, 1233-1245 (2011) https://doi.org/10.1007/s00122-010-1527$\mathrm{y}$

3. S.J. Kanwar, I.S. Naruka, P.P. Singh, Ind. Jour. of Agricult. Sci., 88(5), 737-745 (2018). https://www.researchgate.net/publication/325686349 Genetic variability and associati on among colour and white seedless genotypes of grape Vitis vinifera

4. V. Alba, C. Bergamini, R. Genghi, M. Gasparro, R. Perniola, D. Antonacci, Mol. Biotechnol., 57, 709 (2015) https://doi.org/10.1007/s12033-015-9862-5

5. O. Failla, Vitis, 54 (Spetial Issue), 1-4 (2015) https://doi.org/10.5073/vitis.2015.54. special-issue.1-4

6. E. Maletić, I. Pejić, J. Karoglan Kontić, D. Zdunić, D. Preiner, S. Šimon, Ž. Andabaka, M. Žulj Mihaljević, M. Bubola, Z. Marković, D. Stupić, A. Mucalo, Vitis, 54 (Spetial Issue), 93-98 (2015) https://doi.org/10.5073/vitis.2015.54.special-issue.93-98

7. B. Biagini, G. De Lorenzis, S. Imazio, O. Failla, A. Scienza, Tree Genet. and Genom., 10, 1369-1385 (2014) http://doi.org/10.1007/s11295-014-0767-4

8. G. Zdunić, E. Maul, J. E. J. Eiras Dias, G. Muñoz Organero, F Carka, E. Maletić, S. Savvides, G. G. Jahnke, Z. A. Nagy, D. Nikolić, D. Ivanišević, K. Beleski, V. Maraš, M. Mugoša, V. Kodzulovic, T. Radić, K. Hančević, A. Mucalo, K. Lukšić, L. Butorac, L. Maggioni, A. Schneider, T. Schreiber, T. Lacombe, Vitis, 56(3), 127-131 (2017). https://doi.org/10.5073/vitis.2017.56.127-131

9. A. Marrano, L. Grzeskowiak, P. Moreno Sanz, S. Lorenzi, M. L. Prazzoli, A. Arzumanov, M. Amanova, O. Failla, D. Maghradze, M. S. Grando, Vitis, 54 (Spetial Issue), 233-237 (2015) https://doi.org/10.5073/vitis.2015.54.special-issue.233-237

10. V. Laucou, A. Launay, R. Bacilieri, T. Lacombe, A.F. Adam-Blondon, A. Bérard, A. Chauveau, M.T. de Andrés, L. Hausmann, J. Ibáñez, M.C. Le Paslier, D. Maghradze, J.M. Martinez-Zapater, E. Maul, M. Ponnaiah, R. Töpfer, J.P. Péros, J.M. Boursiquot, Plos One, 13(2), e0192540 (2018) https://doi.org/10.1371/journal.pone.0192540

11. F. Pelsy, S. Hocquigny, X. Moncada, G. Barbeau, D. Forget, P. Hinrichsen, D. Merdinoglu, Theor. Appl. Genet., 120, 1219-1231 (2010) https://doi.org/10.1007/ s00122-009-1250-8

12. S. Riaz, D. Pap, J. Uretsky, V. Laucou, J.M. Boursiquot, L. Kocsis, M.A. Walker, Theor Appl Genet., 132, 1847-1860 (2019) https://doi.org/10.1007/s00122-019-03320-5

13. E. Zyprian, I. Ochßner, F. Schwander, S. Šimon, L. Hausmann, M. Bonow-Rex, P. MorenoSanz, M.S. Grando, S. Wiedemann-Merdinoglu, D. Merdinoglu, R. Eibach, R. Töpfer, Mol Genet Genomics., 291, 1573-1594 (2016) https://doi.org/10.1007/s00438-016-1200-5

14. E. Gonçalves, A. Martins, In: I. Abdurakhmonov (eds), Plant Breeding, (InTech, 333-352, 2012) http://doi.org/10.5772/27903

15. S. Myles, A.R. Boyko, C.L. Owens, P.J. Brown, F. Grassi, M.K. Aradhya, B. Prins, A. Reynolds, J.M. Chia, D. Ware, C.D. Bustamante, E.S. Buckleret, PNAS, 108 (9), 35303535 (2011) https://doi.org/10.1073/pnas.1009363108

16. E.T. Ilnitskaya, S.V. Tokmakov, M.V. Makarkina, I.I. Suprun, Acta Hortic., 1248, 129-134 (2019) https://doi.org/10.17660/ActaHortic.2019.1248.19

17. I.V. Gorbunov, Fruit growing and viticulture in the South of Russia, 59(5), 31-38 (2019). https://doi.org/10.30679/2219-5335-2019-5-59-31-38

Ivan Gorbunov 
Иван Горбунов

8 (938) 506-42-97

wunsch27@,mail.ru

Anapa Zonal Experimental Station of Viticulture and Wine-making - branch of Federal State Budget Scientific Institution "North Caucasian Federal Scientific Center of Horticulture, Viticulture, Wine-making"

Анапская зональная опытная станция виноградарства и виноделия - филиал ФГБНУ Северо-Кавказского федерального научного центра садоводства, виноградарства, виноделия

Head of the Laboratory of Viticulture and Winemaking, Cand. Bio. Sci., Research Associate Заведующий лабораторией «Виноградарство и виноделие», к.б.н., н.с.

Станислав Михайловский

Stanislav Mikhaulovskiy

8 (918) 368-12-40

rivacase@inbox.ru

Anapa Zonal Experimental Station of Viticulture and Wine-making - branch of Federal State Budget Scientific Institution "North Caucasian Federal Scientific Center of Horticulture, Viticulture, Wine-making"

Анапская зональная опытная станция виноградарства и виноделия - филиал ФГБНУ Северо-Кавказского федерального научного центра садоводства, виноградарства, виноделия

Junior Research Associate of Laboratory of Viticulture and Winemaking

М.н.с. лаборатории «Виноградарство и виноделие».

Olga Byhalova

Ольга Быхалова

9184739988@,mail.ru

Federal State Budgetary Institution "State Nature Reserve "Utrish"

Федеральное государственное бюджетное учреждение «Государственный природный заповедник «Утриш»

Deputy Director of the Reserve

Заместитель директора заповедника 